\title{
STUDIES OF HEMOGLOBINEMIA AND HEMOGLOBINURIA PRODUCED IN MAN BY INTRAVENOUS INJECTION OF HEMOGLOBIN SOLUTIONS
}

\author{
By D. ROURKE GILLIGAN, MARK D. ALTSCHULE, AND EVELYN M. KATERSKY \\ (From the Medical Service and the Medical Research Laboratories, Beth Israel Hospital, \\ and the Department of Medicine, Harvard Medical School, Boston)
}

(Received for publication October 18, 1940)

Hemoglobinuria is a striking feature of several hemolytic disorders, such as blackwater fever, the various paroxysmal hemoglobinurias, and certain types of acute hemolytic anemia. Available information indicates that hemoglobinuria in these conditions results from intravascular hemolysis with liberation of hemoglobin into the plasma.

Quantitative studies of the plasma and urine hemoglobin and of pigments derived from hemoglobin have been made recently in this laboratory on several patients with hemoglobinuria. It was thought that comparison of the findings in normal individuals in whom hemoglobinemia and hemoglobinuria were induced by intravenous injections of hemoglobin solutions, together with the findings in clinical cases showing hemoglobinuria, might clarify certain aspects of these clinical problems.

Sellards and Minot (1), Duesberg (2), and Ottenberg and Fox (3) have demonstrated that small amounts of stroma-free solutions of human hemoglobin may be injected in man without serious toxic reactions. The findings of these authors will be discussed below.

\section{METHODS}

Preparation and injection of hemoglobin solutions. The hemoglobin solutions were prepared essentially as described by Sellards and Minot (1) and by Ottenberg and Fox (3). In some instances "bank" blood, discarded for intravenous use ten days after collection, was used as the source of hemoglobin without regard to the blood group; when this was not available, fresh blood was collected, using sodium citrate as the anticoagulant. The cells were washed three times with physiological saline, then laked with four volumes of fresh distilled water maintained at approximately $37^{\circ} \mathrm{C}$. for one hour, with frequent shaking. An amount of freshly prepared 18 per cent saline solution equivalent to $1 / 20$ of the volume of hemoglobin solution was added with resultant clouding, apparently due to aggregation of stromata. The solution was centrifuged for an hour and the clear supernatant fluid carefully removed and filtered through a Seitz filter to remove micro-organisms and remaining stromata (3); then it was inspected for cloudiness or particulate matter and a culture in broth was made to ascertain its sterility. As noted previously (3), the solution, after centrifuging and before filtering through the Seitz filter, would repeatedly show further clouding on addition of a few more drops of the hypertonic saline solution. However, after filtration through the Seitz filter, clouding with additional saline no longer occurred. Passage through the Seitz filter was extremely slow; accordingly, when the larger volumes were prepared, the solutions were first filtered without sterilizing the apparatus, and the filter pad was changed as filtration became slowed. The entire amount was then passed again through a sterilized Seitz filter. The concentration of hemoglobin in the solution was measured by the Evelyn method.

From $20 \mathrm{cc}$. to $280 \mathrm{cc}$. of the solution were injected into an antecubital vein at the rate of approximately 20 to $30 \mathrm{cc}$. per minute. Before injection of the larger volumes of hemoglobin solutions the subject's urine was made alkaline by oral administration of sodium bicarbonate and was maintained alkaline throughout the period of hemoglobinuria. A glass of water was taken approximately every hour in addition to the fluid of meals. These precautions against possible kidney damage due to hemoglobin products are based on the observations of Baker and Dodds (4) and others.

Chemical methods. Venous blood was drawn as suggested by Ham (5) with a sterile syringe and needle which had been rinsed several times with sterile physiological saline solution. The blood was transferred to a tube containing a volume of 3 per cent sodium citrate solution equivalent to 10 per cent of the volume of blood, and gently mixed. The sample was centrifuged immediately and the plasma separated with care to avoid any contamination with red cells. The hematocrit value was measured on a blood sample using oxalate mixture as the anticoagulant (6). The dilution of the plasma by the citrate solution was calculated and the plasma hemoglobin and bilirubin values were corrected accordingly.

The concentration of hemoglobin in the plasma and urine was measured by the benzidine method essentially as described by Bing and Baker $(7,8)$. The stock hemoglobin solution used by Bing and Baker is not stable. A fresh hemoglobin standard was made daily by diluting $0.5 \mathrm{cc}$. of blood of normal hemoglobin concentration to $2000 \mathrm{cc}$. with distilled water. The hemoglobin concentration of the blood was measured with the Evelyn colorimeter (9). Control plasmas were diluted one to 10 with water and $1.0 \mathrm{cc}$. was taken for 
INTRAVENOUS .INJECTIONS OF HEMOGLOBIN IN NORMAL SUBJECTS.
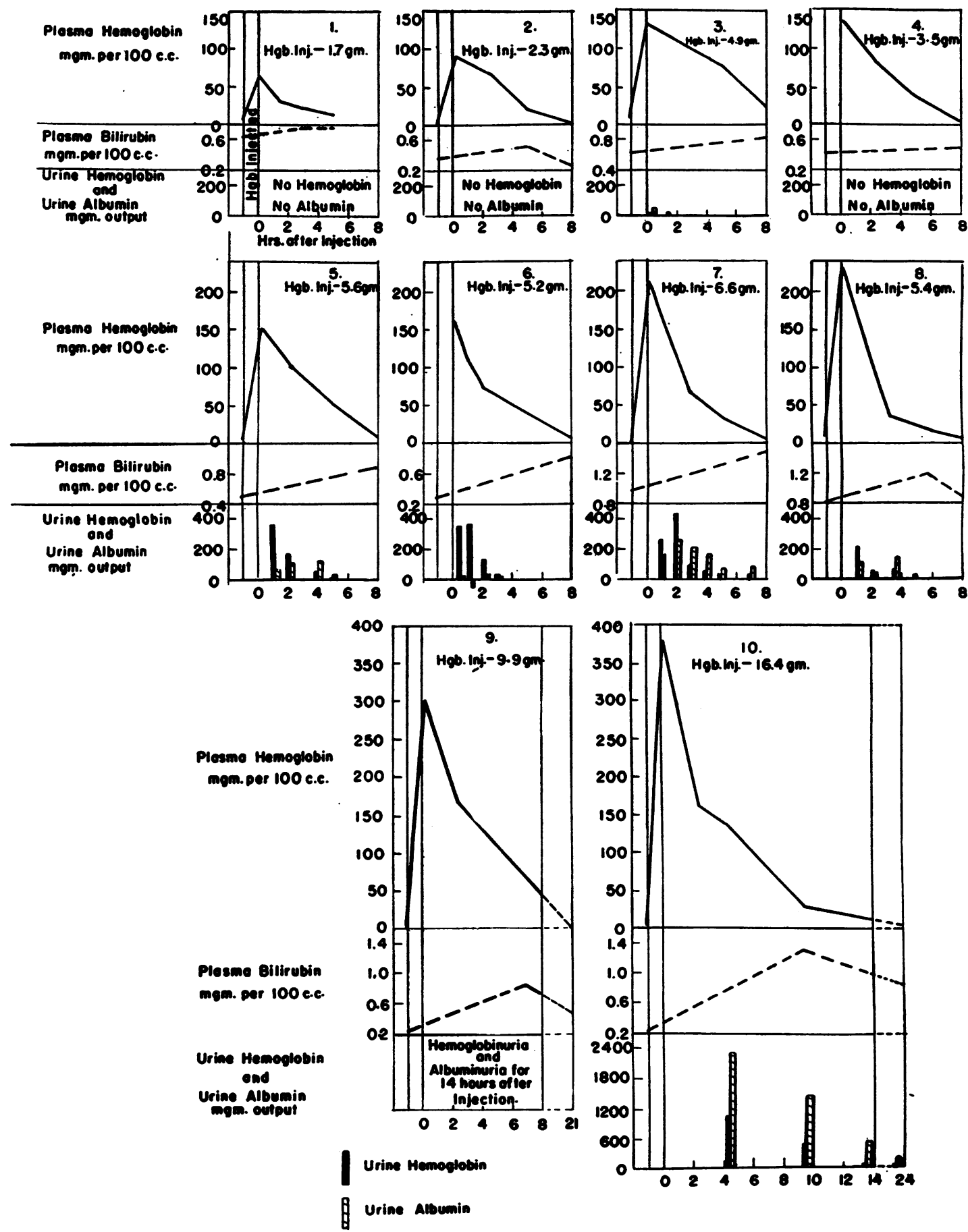

Fig. 1. The Hemoglobin and Bilirubin Concentrations of the Plasma, and the Hemoglobin and Albumin Excretion in the Urine Following Intravenous Injections of Solutions of Hemoglobin in Normal Subjects

The experiment number is given at the top of each diagram; each experiment was made in a different subject. 
analysis. Appropriately smaller amounts of a one to 10 dilution were used for plasmas of moderate hemoglobin concentration. A one to $\mathbf{5 0}$ dilution was made of plasmas with $200 \mathrm{mgm}$. or more of hemoglobin per $100 \mathrm{cc}$. The hemoglobin standards were made from $0.1,0.2$, and 0.5 cc. of the standard hemoglobin solution so that the unknowns could be read in the colorimeter against a standard which closely matched. Samples of $0.1 \mathrm{cc}$. of undiluted urine, or $0.1 \mathrm{cc}$. of a diluted urine equivalent to approximately $5 \mathrm{mgm}$. per $100 \mathrm{cc}$., were used. This amount of an undiluted urine with high specific gravity precipitates some of the benzidine reagent and probably introduces a slight inaccuracy; if amounts of urine are chosen to read against the low standard, no precipitation occurs except in urines of very low hemoglobin concentration, which cannot be diluted. Appropriate amounts of water are added to the tubes containing $2 \mathrm{cc}$. of benzidine reagent to make the total of the unknown or standard hemoglobin samples plus water up to $1 \mathrm{cc}$.

The bilirubin concentration of the plasma was measured by the method of Malloy and Evelyn (10), using the Evelyn colorimeter. It was noted repeatedly that the bilirubin value obtained immediately after the hemoglobin injection was appreciably lower than that of the control blood, suggesting that the presence of hemoglobin interfered with the bilirubin measurement. Accordingly, hemoglobin solutions were added to normal plasma samples to give various final concentrations of hemoglobin and the effect on the bilirubin was measured. The bilirubin values were corrected for the 10 per cent dilution caused by the addition of the hemoglobin solution. The values obtained when the concentration of hemoglobin in the plasma was $30 \mathrm{mgm}$. per $100 \mathrm{cc}$., or over, were appreciably lower than those of the hemoglobin-free plasma (Table I). Consequently, the values for bilirubin obtained on plasma samples containing $30 \mathrm{mgm}$. of hemoglobin, or over, have been discarded except in one instance (Figure 1, Experiment 9).

The urea clearance was measured by the method of Van Slyke, Page, Hiller, and Kirk (11). The "urea plus ammonia" nitrogen was measured after urease action by the aeration method.

Urine "albumin" was measured quantitatively by determining the total amount of protein precipitated by trichloracetic acid and subtracting from this the amount of hemoglobin as determined by the benzidine method. The method utilized to measure the total concentration of protein was as follows: In a weighed centrifuge tube the protein of $5 \mathrm{cc}$. of urine was precipitated with $5 \mathrm{cc}$. of 20 per cent trichloracetic acid. The mixture was allowed to stand overnight and was then centrifuged at high speed. The supernatant fluid was decanted as completely as possible. Ten cc. of 10 per cent trichloracetic acid was added to the precipitate, the mixture was stirred well and allowed to stand a few hours. The mixture was again centrifuged and the supernatant fluid was decanted. The tube was wiped clean on the outside, dried in the oven at $100^{\circ} \mathrm{C}$. overnight and weighed after cooling in the desiccator. The weight of the precipitate
TABLE I

Effect of hemolysis on plasma bilirubin values obtained by the Malloy and Evelyn method (10)

\begin{tabular}{|c|c|c|c|c|c|}
\hline \multirow{3}{*}{$\begin{array}{l}\text { Experi- } \\
\text { ment } \\
\text { num- } \\
\text { ber }\end{array}$} & \multirow{2}{*}{$\begin{array}{l}\text { Control } \\
\text { plasma }\end{array}$} & \multicolumn{4}{|c|}{$\begin{array}{l}\text { Final hemoglobin concentration of } \\
\text { plasma after adding hemoglobin }\end{array}$} \\
\hline & & $\begin{array}{l}12 \mathrm{mgm} . \\
\text { per } 100 \mathrm{cc} .\end{array}$ & $\begin{array}{l}30 \mathrm{mgm} . \\
\text { per } 100 \mathrm{cc} .\end{array}$ & $\begin{array}{l}60 \mathrm{mgm} . \\
\text { per } 100 \mathrm{cc} .\end{array}$ & $\begin{array}{l}120 \mathrm{mgm} \text {. } \\
\text { per } 100 \mathrm{cc} \text {. }\end{array}$ \\
\hline & Bilirubin & Bilirubin & Bilirubin & Bilirubin & Bilirubin \\
\hline $\begin{array}{l}1 \\
2 \\
3 \\
4 \\
5 \\
6 \\
7\end{array}$ & $\begin{array}{c}\text { mgm. per } \\
100 \text { cc. } \\
0.69 \\
0.83 \\
0.18 \\
0.20 \\
0.49 \\
0.84 \\
0.92\end{array}$ & $\begin{array}{c}\text { mgm. per } \\
100 \text { cc. } \\
0.69 \\
0.87\end{array}$ & $\begin{array}{l}0.17 \\
0.18 \\
0.35 \\
0.67\end{array}$ & $\begin{array}{l}0.21 \\
0.19 \\
0.31 \\
0.69 \\
0.63\end{array}$ & $\begin{array}{l}\text { mgm. per } \\
100 \text { cc. }\end{array}$ \\
\hline
\end{tabular}

was multiplied by 20 to give the concentration of total protein in $100 \mathrm{cc}$. of urine. Experiments with solutions of known hemoglobin concentration and of known albumin concentration gave satisfactory results with this simple method. Acetic acid and tungstic acid precipitations were tried with very unsatisfactory precipitation of protein in urines containing hemoglobin and very little albumin.

Spectroscopic examinations of plasma and urine were made with a Zeiss hand spectroscope. In one instance spectrophotometric examination of the urine was made with a König-Martens type of spectrophotometer.

\section{RESULTS}

Fifteen intravenous injections of hemoglobin solutions, varying in volume from 20 to $280 \mathrm{cc}$. and in total hemoglobin content from 1.3 to 16.4 grams, were made. Ten injections were made in subjects who may be considered normal for the purposes of this study, four were made in patients with congestive heart failure and albuminuria, and one in a subject with carcinoma of the colon with metastases to the liver and a blood hemoglobin level of 40 per cent.

In twelve instances there were no febrile or other untoward reactions. One subject (Figure 2, Experiment 14) with bronchial asthma and congestive heart failure experienced transitory chills and fever after receiving $35 \mathrm{cc}$. of hemoglobin solution containing 1.9 grams of hemoglobin. In the two subjects (Figure 1, Experi-. ments 9 and 10) in whom the largest amounts of hemoglobin were injected, i.e., 10 grams and 16 grams, severe abdominal cramps with vomiting and visible peristalsis were experienced, coming 


\section{INTRAVENOUS HEMOGLOBIN INJECTIONS IN SUBJECTS WITH CONGESTIVE HEART FAILURE AND ALBUMINURIA}
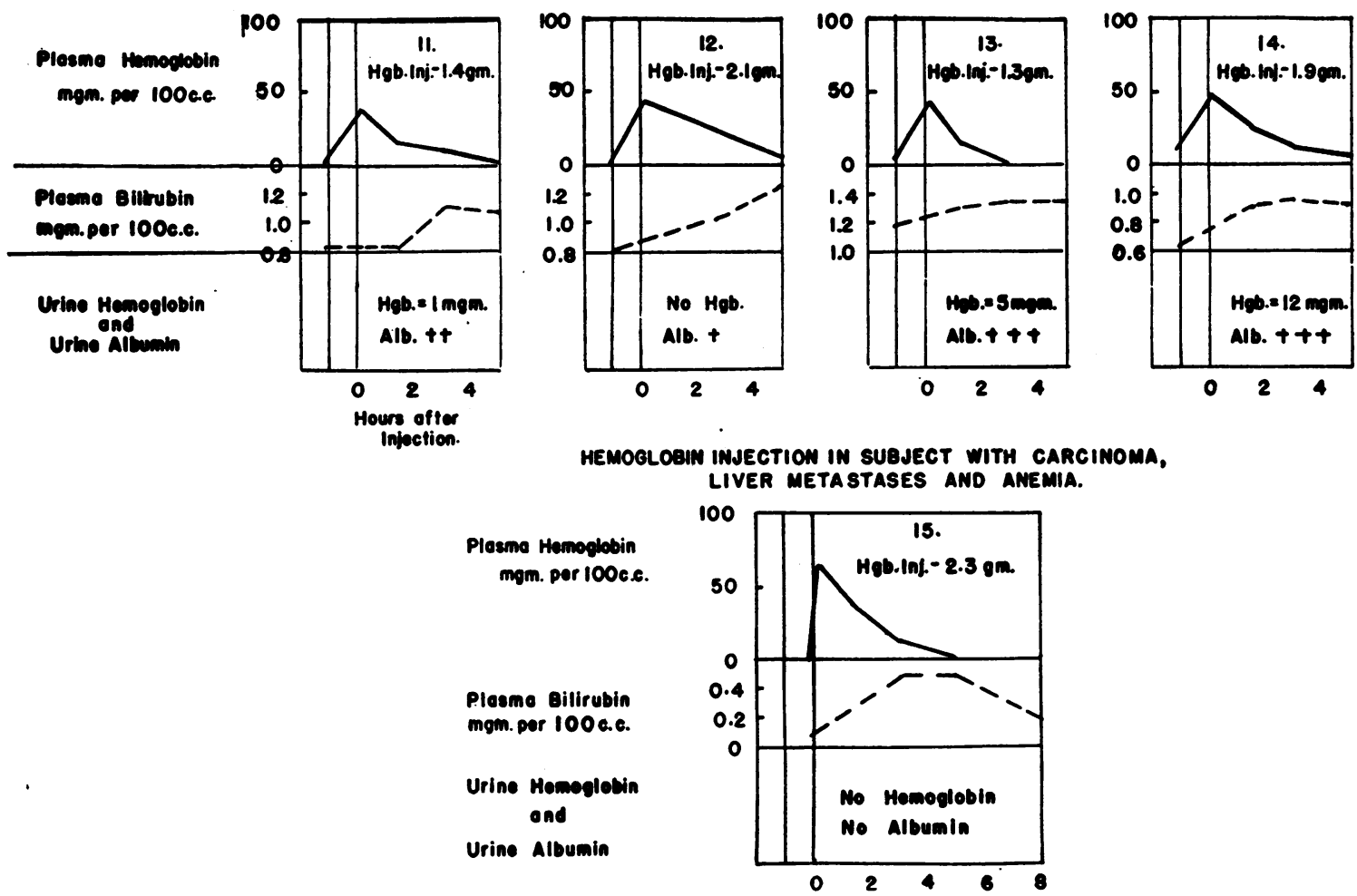

Fig. 2. The Hemoglobin and Bilirubin Concentrations of the Plasma, and the Hemoglobin and Albumin Excretion in the Urine Following Intravenous Injections of Solutions of Hemoglobin in Patients with Congestive Heart Failure, and in a Case with Carcinoma, Liver Metastases and Anemia

The experiment number is given at the top of each diagram; Experiments 11 and 12 were made in the same subject.

on about forty minutes after the injections and relieved immediately by calcium chloride given intravenously; the second subject, who received 16 grams of hemoglobin, had a moderate chill preceding the onset of the abdominal cramps, pains in the legs, and slight fever lasting for fifteen hours.

\section{Hemoglobinemia}

The plasma hemoglobin was elevated by the injection of the hemoglobin solutions to values of 40 to $380 \mathrm{mgm}$. per $100 \mathrm{cc}$. (Figures 1 and 2). When levels of 40 to $60 \mathrm{mgm}$. of hemoglobin per $100 \mathrm{cc}$. were induced, approximately five hours were required for the plasma to be cleared of hemoglobin; with levels of 150 to $225 \mathrm{mgm}$. per $100 \mathrm{cc}$., about eight hours were required for clearing. In two studies in which levels of 280 and
$380 \mathrm{mgm}$. of hemoglobin per $100 \mathrm{cc}$. of plasma were induced, the plasma hemoglobin did not reach normal for approximately twelve hours.

The curves representing removal of hemoglobin from the plasma show a more rapid rate of fall at the higher hemoglobin levels (Figures 1 and 2). Although there is considerable variation in different experiments, calculation of the average rate of drop at varying levels of plasma hemoglobin is of interest. The data of Ottenberg and Fox (3), as well as the data of this paper, have been utilized for this estimation (Table II); the averages of the two sets of data agree closely. Whereas the average rate of decline of plasma hemoglobin from $50 \mathrm{mgm}$. to $10 \mathrm{mgm}$. per $100 \mathrm{cc}$. is only $10 \mathrm{mgm}$. per $100 \mathrm{cc}$. per hour, the average rate of fall from approximately 250 to $150 \mathrm{mgm}$. per $100 \mathrm{cc}$. is $47 \mathrm{mgm}$. per $100 \mathrm{cc}$. per hour (Figure 3). 
TABLE II

Average rate of disappearance of hemoglobin from the plasma at various hemoglobin levels

\begin{tabular}{|c|c|c|c|c|c|}
\hline \multirow{2}{*}{ Author } & \multicolumn{2}{|c|}{$\begin{array}{c}\text { Plasma } \\
\text { hemoglobin }\end{array}$} & \multirow{2}{*}{$\begin{array}{c}\text { Aver- } \\
\text { age } \\
\text { mid- } \\
\text { point }\end{array}$} & \multirow{2}{*}{$\begin{array}{c}\text { Average } \\
\text { rate of } \\
\text { fall of } \\
\text { plasma } \\
\text { hemo- } \\
\text { globin }\end{array}$} & \multirow{2}{*}{$\begin{array}{l}\text { Num- } \\
\text { ber of } \\
\text { stud- } \\
\text { ies }\end{array}$} \\
\hline & $\begin{array}{l}\text { High } \\
\text { level }\end{array}$ & $\begin{array}{l}\text { Low } \\
\text { level }\end{array}$ & & & \\
\hline & $\begin{array}{l}\text { mgm. per } \\
100 \mathrm{cc} .\end{array}$ & $\begin{array}{c}\text { mgm. } \\
\text { per } \\
100 \\
\text { cc. }\end{array}$ & $\begin{array}{c}\text { mgm. } \\
\text { per } \\
100 \\
c c .\end{array}$ & $\begin{array}{l}\text { mgm. per } \\
100 \text { ce. } \\
\text { per hour }\end{array}$ & \\
\hline $\begin{array}{l}\text { Gilligan et al* } \ldots \ldots \ldots \\
\text { Ottenberg and Fox** } \\
\text { Average............ }\end{array}$ & $\begin{array}{l}50 \\
50\end{array}$ & $\begin{array}{l}10 \\
10\end{array}$ & $\begin{array}{l}30 \\
30 \\
30\end{array}$ & $\begin{array}{l}10 \\
10 \\
10\end{array}$ & $\begin{array}{l}8 \\
5\end{array}$ \\
\hline $\begin{array}{l}\text { Gilligan et al......... } \\
\text { Ottenberg and Fox.... } \\
\text { Average............ }\end{array}$ & $\mid \begin{array}{c}132-150 \\
150\end{array}$ & $\begin{array}{l}50 \\
50\end{array}$ & $\begin{array}{r}98 \\
100 \\
99\end{array}$ & $\begin{array}{l}29 \\
27 \\
28\end{array}$ & $\begin{array}{l}8 \\
7\end{array}$ \\
\hline $\begin{array}{l}\text { Gilligan et al. } \ldots \ldots \\
\text { Ottenberg and Fox } \ldots \ldots \\
\text { Average............. }\end{array}$ & $\begin{array}{l}212-295 \\
202-288\end{array}$ & \begin{tabular}{|l|}
150 \\
150
\end{tabular} & $\begin{array}{l}202 \\
201 \\
201\end{array}$ & $\begin{array}{l}49 \\
46 \\
47\end{array}$ & $\begin{array}{l}4 \\
8\end{array}$ \\
\hline
\end{tabular}

* Data of this paper.

** Data of Ottenberg and Fox (3).

\section{Hemoglobinuria}

In three normal subjects and in one patient with carcinoma and anemia in whom plasma levels of from 60 to $135 \mathrm{mgm}$. per $100 \mathrm{cc}$. were induced, no hemoglobin appeared in the urine (Figures 1 and 2). Hemoglobinuria occurred in seven cases in which the plasma hemoglobin levels after injection were 135 to $380 \mathrm{mgm}$. per $100 \mathrm{cc}$. The amounts of hemoglobin excreted in the urine were roughly proportional to the height of the plasma hemoglobin following injection. In Experiment 3 , in which the plasma hemoglobin after injection was $135 \mathrm{mgm}$. per $100 \mathrm{cc}$., hemoglobin appeared only in the urine specimen voided one-half hour after injection and the total amount excreted was only 0.003 gram; in Experiment 10 , in which the plasma hemoglobin was $380 \mathrm{mgm}$. per $100 \mathrm{cc}$. after injection, 1.6 grams of hemoglobin were excreted in the urine during the first ten hours after injection.

In three cases with congestive heart failure and albuminuria small amounts of hemoglobin were excreted after injections which produced plasma levels of only 38 to $49 \mathrm{mgm}$. of hemoglobin per 100 cc. (Figure 2). (The albumin concentrations in the urine before injection were 0.1 to 0.4 gram per cent.) The total amount of hemoglobin excreted was 0.001 gram to 0.012 gram. In one of these cases (Experiment 13) a distinctly red-

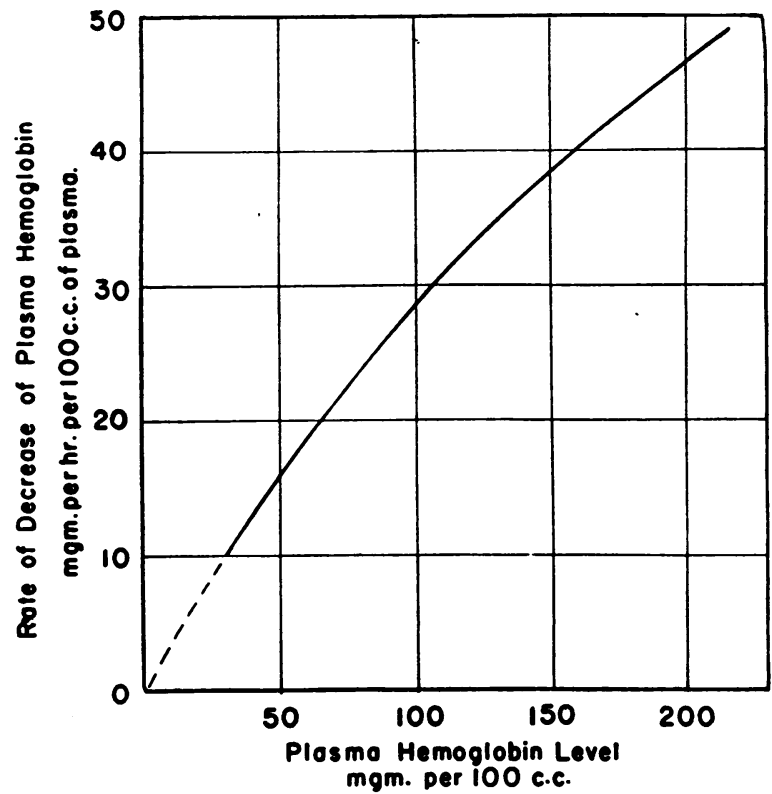

Fig. 3. Average Rate of Decrease of the Hemoglobin Concentration of the Plasma at Varying Levels of Plasma Hemoglobin following Intravenous InJections of Hemoglobin Solutions

The data from which this curve has been constructed are given in Table II.

dish tint was present in small amounts of urine voided one-half, and one and one-quarter hours after injection. These urine specimens contained 16 and $11 \mathrm{mgm}$. of hemoglobin per $100 \mathrm{cc}$., respectively. In the two other cases the urine contained 3 and $5 \mathrm{mgm}$. of hemoglobin per $100 \mathrm{cc}$.; these specimens were not obviously discolored. In one of these patients a second injection of hemoglobin inducing a plasma level of $42 \mathrm{mgm}$. per $100 \mathrm{cc}$. failed to produce hemoglobinuria (Figure 2, Experiment 12); at this time cardiac decompensation was less severe and the urine albumin was only 0.02 gram per cent before injection.

Spectroscopic examination of fresh urines with the hand spectroscope revealed only oxyhemoglobin. No precipitated hemoglobin products were found. A spectrophotometric ${ }^{1}$ examination of one fresh urine which was acid when voided revealed a point of maximum absorption at 576 $\mathrm{m} \mu$, which corresponds with the alpha band of oxyhemoglobin (12). In addition, there was a very

1 This spectrophotometric examination was performed by Dr. John F. Taylor of the Department of Biological Chemistry of the Harvard Medical School. 
faint point of absorption at $630 \mathrm{~m} \mu$, indicating the presence of an appreciable amount of methemoglobin (12).

\section{Albuminuria}

Quantitative studies of the total protein of the urine were made as described above. When hemoglobin was present in the urine, the amount of hemoglobin as measured by the benzidine method was subtracted from the total amount of protein and the remaining protein was considered to be chiefly albumin. The positive identification of this protein as albumin was not accomplished because of the large amount of material required and the difficulty of the procedure of identification.

No albumin appeared in the urine of the normal subjects who received insufficient amounts of hemoglobin to cause hemoglobinuria. In normal subjects receiving amounts of hemoglobin sufficient to cause hemoglobinuria the " albumin" excretion was variable. In one subject (Experiment 6 ), in whom a total of 0.87 gram of hemoglobin was excreted in the urine during the first three hours after injection, there was no albuminuria, the total protein excretion being the same, within experimental error, as the hemoglobin excretion. In another case (Experiment 10), the total amount of protein was 6.2 grams, 1.6 grams of which were hemoglobin and 4.6 grams presumably albumin. In the other five normal subjects who showed hemoglobinuria (Figure 1), the total amount of " albumin" excreted was approximately equal to, or somewhat less than, the total amount of hemoglobin excreted. When "albumin" was present in the urine it usually continued to be excreted in concentrations of 10 to $50 \mathrm{mgm}$. per $100 \mathrm{cc}$. of urine for one-half to one hour after hemoglobinuria ceased.

\section{Bilirubinemia}

The plasma bilirubin increased after injection of hemoglobin in every instance (Figures 1 and 2). In normal subjects, injections inducing plasma hemoglobin levels of 60 to $130 \mathrm{mgm}$. per $100 \mathrm{cc}$. caused an increase in bilirubin during the six to eight hours after injection of only 0.1 to $0.2 \mathrm{mgm}$. per $100 \mathrm{cc}$. of plasma over the control values. In studies in which the plasma hemoglobin was elevated to 150 to $230 \mathrm{mgm}$. per 100 cc., the bilirubin increased 0.4 to $0.5 \mathrm{mgm}$. per 100 cc. of plasma and, after two injections in which hemoglobin levels of 280 and $380 \mathrm{mgm}$. per 100 cc. were induced, the bilirubin increases amounted to 0.6 and $1.1 \mathrm{mgm}$. per $100 \mathrm{cc}$., respectively.

In the three subjects with congestive heart failure and in the patient with carcinoma and anemia, hemoglobin injections which induced plasma hemoglobin levels of only 40 to $60 \mathrm{mgm}$. per $100 \mathrm{cc}$. caused bilirubin increases of 0.2 to $0.4 \mathrm{mgm}$. per $100 \mathrm{cc}$. of plasma (Figure 2).

The plasma bilirubin appeared to return to the control value a few hours after the hemoglobin disappeared from the plasma in studies in which the smaller amounts of hemoglobin were injected (Figure 1). In Experiment 10 the plasma bilirubin rose from a control level of $0.2 \mathrm{mgm}$. to $1.3 \mathrm{mgm}$. per $100 \mathrm{cc}$. ten hours after the injection of 16 grams of hemoglobin. The plasma hemoglobin level ten hours after the injection was still elevated to $28 \mathrm{mgm}$. per $100 \mathrm{cc}$. so that, presumably, the bilirubin may have increased slightly further in the next two hours. Twenty-four hours after the injection the bilirubin level had fallen to $0.9 \mathrm{mgm}$. per $100 \mathrm{cc}$.

\section{Kidney function}

Examination of the urinary sediment during periods of hemoglobinuria revealed nothing abnormal ; no hemosiderin, hemoglobin casts or other precipitated hemoglobin products were found on examination of fresh urines. "Albuminuria," as mentioned above, was usually present during the period of hemoglobinuria and for approximately an hour thereafter.

None of the patients complained of pains in the back or burning on micturition.

The urea clearance was studied in one case (Experiment 7) in which injection of hemoglobin induced a plasma hemoglobin level of $212 \mathrm{mgm}$. per $100 \mathrm{cc}$. The fluid intake was maintained constant for several hours before and after the injection. The average urea clearance for three one-hour periods preceding the injection was 83 per cent of normal, and for the first three hours following injection, during which a total of 800 mgm. of hemoglobin was excreted in the urine, the average urea clearance was 76 per cent of normal. The average urine volume for the three hours before injection was $1.97 \mathrm{cc}$. per minute, 
and for the three hours after injection, $1.82 \mathrm{cc}$. per minute.

\section{Clinical observations}

The body temperature was not affected by the hemoglobin injections except in the two instances already described in which chills and fever occurred. There were no symptoms other than the untoward reactions already mentioned. The injections did not cause the spleen and liver to become palpable and produced no clinical icterus.

\section{DISCUSSION}

The total amount of stroma-free hemoglobin solution administered in these studies was injected intravenously in from one to ten minutes; the results obviously would have been quite different if the same amounts of hemoglobin were administered by slow intravenous drip.

Toxic reactions occurred in three of the fifteen subjects. In two subjects abdominal cramps with vomiting and visible peristalsis, associated in one instance with transitory chills and fever, occurred following the injections of 10 grams and 16 grams of hemoglobin; these gastro-intestinal symptoms were relieved immediately by the injection intravenously of a solution of calcium chloride. The third subject experiencing a reaction had received only 2 grams of hemoglobin, following which transitory chills and fever occurred; this patient had a history of asthma and other allergic manifestations of thirty years' duration. Sellards and Minot (1) observed transitory chills and fever after the injection of approximately 10 grams of hemoglobin in solution in one normal subject. O'Shaughnessy (13) observed untoward reactions, namely chills and fever, pain in the back and loins, or sensations of constriction in the chest, following the intravenous injection of 10 to 50 grams of hemoglobin in solution in four patients with anemia. Fairley (14) observed nausea and fever in one subject after an intravenous injection of 21 grams of hemoglobin in solution and no untoward reactions in two subjects after injections of 14 and 17 grams of hemoglobin. The chills and fever, the pains in the back and loins, and the feeling of constriction in the chest experienced by some subjects after intravenous injections of 10 grams or more of hemoglobin in solution are also noted in transfusion reactions and in other clinical hemolytic syndromes $(15,16)$ with or without hemoglobinemia. The immediate relief, following the intravenous administration of calcium chloride, of the severe abdominal pain, vomiting, and visible peristalsis which occurred in two subjects of this study suggests that these reactions were due to marked spasm of the smooth muscle of the gastro-intestinal tract. Similar abdominal crises occur in several clinical hemolytic syndromes $(15,16,17)$. The laking of red blood cells releases appreciable amounts of a histaminelike substance (18) and of potassium (19), either one of which may cause constriction of smooth muscle.

Hemoglobinuria did not occur in the normal subjects in whom plasma hemoglobin levels of less than $135 \mathrm{mgm}$. per $100 \mathrm{cc}$. were induced but did occur in all instances when levels of 135 to 380 mgm. per $100 \mathrm{cc}$. were induced. Always less than 15 per cent of the injected hemoglobin was excreted in the urine. Sellards and Minot (1) observed hemoglobinuria in some normal subjects in whom amounts of hemoglobin presumably sufficient to induce plasma hemoglobin levels of approximately 150 to $300 \mathrm{mgm}$. per $100 \mathrm{cc}$. were injected, whereas hemoglobinuria did not occur after injections of smaller amounts of hemoglobin. Ottenberg and Fox (3) observed hemoglobinuria in four of eight studies of normal subjects with plasma hemoglobin concentrations of 110 to 150 mgm. per $100 \mathrm{cc}$. after injections of hemoglobin intravenously, and in nine of fifteen studies in which plasma levels of 175 to $320 \mathrm{mgm}$. per 100 cc. were induced. Thus, hemoglobinuria may occur in normal subjects when the plasma hemoglobin level is somewhat over $100 \mathrm{mgm}$. per 100 cc. but may be absent even at levels of almost 300 mgm. per $100 \mathrm{cc}$. Once hemoglobin has appeared in the urine, excretion continues in small amounts until the plasma hemoglobin level has decreased to 30 to $50 \mathrm{mgm}$. per $100 \mathrm{cc}$. (Figure 1 ).

The mechanism of the urinary excretion of hemoglobin is not entirely clear. Lichty, et al (20) conclude from experiments in dogs that hemoglobin passes the glomerular filter at plasma levels ("the renal threshold") considerably below those required to cause hemoglobinuria, but that the hemoglobin may fail to appear in the bladder urine because the filtered hemoglobin is rapidly 
taken up and, in part at least, deposited within the tubular epithelium. When, however, the tubular cells become saturated with hemoglobin, hemoglobinuria occurs. On the basis of results of simultaneous creatinine and hemoglobin clearance studies in dogs, Monke and Yuile (21) have suggested that 3 per cent of the pores of the glomerular membrane are normally electrostatically large enough to permit the passage of an undissociated hemoglobin molecule.

Gersch (22) concluded that temporary renal injury, causing increased glomerular permeability and thereby allowing the filtration of hemoglobin, occurs in rabbits following intravenous injections of hemoglobin solutions. Hemoglobin, like serum albumin, has a molecular weight of $68,000 .^{2}$ Kerridge and Bayliss (23) found that Bence-Jones protein and other proteins with molecular weights of approximately 35,000 were freely excreted by the kidneys of various animals; "foreign" serum albumin with molecular weight of 68,000 was not excreted and hemoglobin with the same molecular weight was excreted in instances when the plasma hemoglobin level was high; "foreign" serum globulin with molecular weight of 104,000 and other proteins with still higher molecular weights were not excreted. These authors (23) conclude that proteins are excreted by the normal kidney according to the physical size of their molecules, but that hemoglobin has a peculiar place in this scheme. In our study small amounts of hemoglobin appeared in the urine at very low plasma hemoglobin levels after hemoglobin injections in the patients with preexistent glomerular injury and albuminuria (Figure 2). Further, it was observed that protein ${ }^{3}$ other than hemoglobin was

2 Whether hemoglobin may be dissociated into smaller molecules in the plasma is open to some question, since recent experiments indicate that dissociation may occur in dilute solution under certain circumstances $(24,25)$; it is presumed, however, that no dissociation occurs in the plasma, since studies in dogs have shown that below a certain plasma concentration hemoglobin does not filter through the glomeruli (20).

3 Although the nature of this protein was not identified, the significance of its presence in the urine in relation to glomerular filtration would seem to be the same, whether the protein is albumin or a plasma protein derived from hemoglobin, since it did not appear in the urine in the absence of hemoglobinuria. usually excreted in considerable amounts in the urine simultaneously with, and for a short time following, the excretion of hemoglobin (Figure $1)$, whereas no proteinuria was observed in the normal subjects who did not develop hemoglobinuria (Figure 1). These findings support the theory that hemoglobin appears in the urine only when the permeability of the glomerular membrane is increased. Several investigators have reported marked spasm of the renal arterioles after hemoglobin injections in animals $(26,27,28)$; ephedrine, which also causes renal arteriolar spasm, may give rise to albuminuria (29). Microscopic examination of the urinary sediment revealed no abnormalities during hemoglobinuria and the urea clearance was not affected. There was no evidence that the hemoglobin injections in these studies produced any permanent kidney damage. Temporary or permanent renal insufficiency is observed, on the other hand, in several clinical syndromes associated with massive and prolonged hemoglobinuria $(5,30,31)$.

As shown in Figure 3, removal of hemoglobin from the plasma after intravenous injection of this protein is more rapid at the higher concentrations of plasma hemoglobin. The rate of fall of plasma hemoglobin during periods of hemoglobinuria was dependent only to a small extent on the rate of removal by the kidneys ; in Experiment 10,10 grams of hemoglobin were removed from the plasma during the first five hours after the injection and only one gram appeared in the urine. The curve of Figure 3 affords a valuable basis of comparison by means of which quantitative plasma hemoglobin values obtained in patients with various hemolytic syndromes leading to hemoglobinemia may be utilized to yield information concerning the amount and rate of intravascular hemolysis occurring in these syndromes $(30,32)$.

After injections inducing plasma hemoglobin levels of 60 to $130 \mathrm{mgm}$. per $100 \mathrm{cc}$., the plasma bilirubin showed increases of only 0.1 to $0.2 \mathrm{mgm}$. per $100 \mathrm{cc}$. However, considerable increases occurred when hemoglobin levels of $150 \mathrm{mgm}$. per $100 \mathrm{cc}$., or greater, were induced by injections of 5 to 16 grams of hemoglobin, demonstrating that the rate of production of bilirubin exceeded the rate of excretion by the liver. The total amount of bilirubin produced by the breakdown of 5 
grams of hemoglobin would be approximately 200 mgm. That bilirubinemia should occur when this amount of hemoglobin is broken down in the course of four hours or so is expected, since in the bilirubin tolerance test in normal individuals the plasma bilirubin does not return to the control level for three or four hours after a single intravenous injection of $50 \mathrm{mgm}$. of bilirubin (33). Duesberg (2) and Fairley (14) have also observed small increases in plasma bilirubin lasting for six to twelve hours after intravenous injections of from 3 to 17 grams of hemoglobin in normal individuals; in cirrhosis of the liver and in cholelithiasis, the bilirubin increases were greater $(2,14)$. In our series, two patients with congestive heart failure and one patient with carcinoma with metastases to the liver and anemia showed bilirubin increases approximately twice as great as in normal individuals receiving the same amounts of hemoglobin. Our data and those of Duesberg (2) and Fairley (14) accord. Ottenberg and Fox (3) state that they observed no increase in plasma bilirubin following the injection of from 4 to 8 grams of hemoglobin in normal individuals. The data showing the degree to which the plasma bilirubin increases when varying levels of hemoglobinemia are induced in normal individuals (Figure 1) afford a basis for estimating the presence or absence of normal liver function in clinical attacks of hemoglobinemia.

Spectroscopic examination of the plasma and of the fresh urine in these cases revealed only oxyhemoglobin; a spectrophotometric examination of urine in one case showed mainly oxyhemoglobin and a small amount of methemoglobin. Methemalbumin, which is observed in the plasma of clinical cases with prolonged hemoglobinemia (14, 30 ), was not observed by spectroscopic or spectrophotometric examination of the plasma of our subjects or of Fairley's subjects (14) after hemoglobin injections. The plasma color was always light to darker red, with no brownish discoloration which occurs in the presence of appreciable amounts of methemalbumin (30). It has been shown in studies in animals that the character of the urinary hemoglobin pigments following intravenous injections of hemoglobin depends on the acidity of the urine $(4,34)$ and on the length of time which the urine remains in the bladder (20).
That the urine in our cases did not contain hemoglobin casts, acid hematin, or sufficient amounts of methemoglobin to be detected spectroscopically is ascribed to the circumstances that the urines were usually kept alkaline during the period of hemoglobinuria and that they were collected at frequent intervals and examined immediately.

\section{SUM MARY}

Fifteen intravenous injections of stroma-free human hemoglobin solutions were made in ten normal individuals, in three patients with albuminuria due to congestive heart failure and in one patient with carcinoma with metastases to the liver and anemia. The amounts of hemoglobin injected varied from 1.3 to 16.4 grams; the entire amounts were injected in from one to ten minutes.

There were no untoward reactions in twelve cases. Two subjects had chills and fever. One of these latter subjects and one additional subject had severe abdominal pains; these two subjects received the largest amounts of hemoglobin administered.

The plasma hemoglobin levels after injection varied from $40 \mathrm{mgm}$. per $100 \mathrm{cc}$. to $380 \mathrm{mgm}$. per $100 \mathrm{cc}$. The rate of decrease of plasma hemoglobin concentration was greater at higher hemoglobin levels. The average rate of decrease at varying levels has been plotted.

Hemoglobin was excreted in the urine in all the normal subjects in whom the plasma hemoglobin was elevated above $135 \mathrm{mgm}$. per $100 \mathrm{cc}$., and did not appear in the urine in normal subjects with plasma hemoglobin levels below $135 \mathrm{mgm}$. per $100 \mathrm{cc}$. Once hemoglobin had appeared in the urine, hemoglobinuria persisted until the plasma hemoglobin had decreased to as low as 30 to 50 mgm. per 100 cc.

Small amounts of hemoglobin were excreted in the urine of the patients with preëxisting albuminuria when the plasma hemoglobin level was elevated to only 40 to $50 \mathrm{mgm}$. per $100 \mathrm{cc}$.

In the normal subjects who did not show hemoglobinuria there was no proteinuria after injection. The concentration of the total protein of the urine during hemoglobinuria was usually greater than the concentration of hemoglobin, and proteinuria usually persisted for about an hour after cessation of hemoglobinuria. The excretion 
of this additional protein, and perhaps the excretion of the hemoglobin. itself, indicate temporary increased permeability of the glomerular capillaries in the subjects with hemoglobinuria. The urea clearance in one subject was the same before and during hemoglobinuria. The hemoglobin injections caused no permanent kidney damage. The mechanism of excretion of hemoglobin by the kidneys has been discussed.

The plasma bilirubin increased after the injection of hemoglobin solution in every instance. The degree of increase varied directly with the degree to which the plasma hemoglobin was increased by the injection. The amount of bilirubin increase after injection of a given amount of hemoglobin was somewhat greater in the patients with congestive heart failure and the patient with carcinoma with metastases to the liver and anemia than in the normal subjects.

The spleen and liver did not become palpable after the hemoglobin injections. Except in the two cases with chills and fever, the body temperature was unaffected.

Information concerning the pathologic physiology of certain clinical syndromes associated with hemoglobinemia can be obtained by comparison of the findings in cases with these syndromes with those of the present study.

\section{BIBLIOGRAPHY}

1. Sellards, A. W., and Minot, G. R., Injection of hemoglobin in man and its relation to blood destruction, with especial reference to the anemias. J. Med. Research, 1916, 34, 469.

2. Duesberg, R., Uber die biologischen Beziehungen des Hämoglobins zu Bilirubin und Hämatin bei normalen und pathologischen Zuständen des Menschen. Arch. f. exper. Path. u. Pharmakol., 1934, 174, 305.

3. Ottenberg, R., and Fox, C. L., Jr., The rate of removal of hemoglobin from the circulation and its renal threshold in human beings. Am. J. Physiol., 1938, 123, 516.

4. Baker, S. L., and Dodds, E. C., Obstruction of the renal tubules during the excretion of haemoglobin. Brit. J. Exper. Path., 1925, 6, 247.

5. Ham, T. H., Studies on destruction of red blood cells. I. Chronic hemolytic anemia with paroxysmal nocturnal hemoglobinuria: an investigation of the mechanism of hemolysis, with observations on five cases. Arch. Int. Med., 1939, 64, 1271.

6. Heller, V. G., and Paul, H., Changes in cell volume produced by varying concentrations of different anticoagulants. J. Lab. and Clin. Med., 1934, 19, 777.

7. Bing, F. C., and Baker, R. W., Determination of hemoglobin in minute amounts of blood by Wu's method. J. Biol. Chem., 1931, 92, 589.

8. Bing, F. C., Purification of benzidine, and an improved reagent, for estimating hemoglobin in blood. J. Biol. Chem., 1932, 95, 387.

9. Evelyn, K. A., A stabilized photoelectric colorimeter with light filters. J. Biol. Chem., 1936, 115, 63.

10. Malloy, H. T., and Evelyn, K. A., The determination of bilirubin with the photoelectric colorimeter. J. Biol. Chem., 1937, 119, 481.

11. Van Slyke, D. D., and others, Studies of urea excretion. IX. Comparison of urea clearances calculated from the excretion of urea, of urea plus ammonia, and of nitrogen determinable by hypobromite. J. Clin. Invest., 1935, 14, 901.

12. Anson, M. L., and others, On the correlation between the spectra of various haemoglobins and their relative affinities for oxygen and carbon monoxide. Proc. Royal Soc. London, Series B, 1924, 97, 61.

13. O'Shaughnessy, L., Mansell, H. E., and Slome, D., Haemoglobin solution as a blood substitute. Lancet, 1939, 2, 1068.

14. Fairley, N. H., The fate of extracorpuscular circulating haemoglobin. Brit. M. J., 1940, 2, 213.

15. Dameshek, W., and Schwartz, S. O., Acute hemolytic anemia (acquired hemolytic icterus, acute type). Medicine, 1940, 19, 231.

16. Mackenzie, G. M., Paroxysmal hemoglobinuria. Medicine, 1929, 8, 159.

17. Campbell, E. H., Jr., Acute abdominal pain in sicle cell anemia. Arch. Surg., 1935, 31, 607.

18. Barsoum, G. S., and Smirk, F. H., Observations on the histamine yielding substance in the plasma and red cells of normal human subjects and of patients with congestive heart failure. Clin. Sc., 1936, 2, 337.

19. Mincev, A., Experimentelle Untersuchungen über das Wesen hämolytischen Shocks bei der Bluttransfusion: IV. Mitteilung, über den Kalium-und Calcium gehalt im Blutserum beim hämolytischen Shock. Arch. f. klin. Chir., 1934, 181, 250.

20. Lichty, J. A., Jr., Havill, W. H., and Whipple, G. H., I. Renal thresholds for hemoglobin in dogs. Depression of threshold due to frequent hemoglobin injections and recovery during rest periods. J. Exper. Med., 1932, 55, 603.

21. Monke, J. V., and Yuile, C. L., The renal clearance of hemoglobin in the dog. J. Exper. Med., 1940, $72,149$.

22. Gersch, I., The site of renal elimination of hemoglobin in the rabbit. Anat. Record, 1936, 65, 371.

23. Kerridge, P. M., and Bayliss, L. E., The physiology of proteinuria and its clinical significance. Lancet, 1932, 2, 785. 
24. Lamn, O., and Polson, A., The determination of diffusion constants of proteins by a refractometric method. Biochem. J., 1936, 30, 528.

25. Tiselius, A., and Gross, D., Messungen der Diffusion von Eiweisskörpern. Kolloid Ztschr., 1934, 66, 11.

26. Reid, W. L., The effect of intravenous injections of distilled water on the kidney. Am. J. Physiol., 1929, 90, 168.

27. Mason, J. B., and Mann, F. C., The effect of hemoglobin on volume of the kidney. Am. J. Physiol., 1931, 98, 181.

28. Hesse, E., and Filatov, A., Experimentelle Untersuchungen über das Wesen des hämolytischen Shocks bei der Bluttransfusion und die therapeutische Beeinflussung desselben. I. Die Nierenfunktionsstörungen im akuten Experiment. Ztschr. f. d. ges. exper. Med., 1933, 86, 211.

29. Starr, I., Jr., The production of albuminuria by renal vasoconstriction in animals and in man. J. Exper. Med., 1926, 43, 31.

30. Altschule, M. D., and Gilligan, D. R., A case of acute massive hemoglobinuria of obscure etiology with jaundice and anemia, showing exacerbation of hemolysis on walking. Clinical and Hematological Studies, and Measurements of the Pigment Metabolism. Arch. Int. Med. (In press.)

31. Fairley, N. H., and Bromfield, R. J., Laboratory studies in blackwater fever. Part III. A new blood pigment in blackwater fever and other biochemical observations. Tr. Roy. Soc. Trop. Med. and Hyg., 1934, 28, 307.

32. Gilligan, D. R., and Blumgart, H. L., March hemoglobinuria. Studies of the clinical characteristics, blood metabolism and mechanism: with observations on three new cases, and review of the literture. Medicine. (In press.)

33. Barron, E. S. G., Bilirubinemia. Medicine, 1931, 10, 77.

34. DeGowin, E. L., Osterhagen, H. F., and Andersch, M., Renal insufficiency from blood transfusion. I. Relation to urinary acidity. Arch. Int. Med., 1937, $59,432$. 